\title{
A novel cytosolic regulator, Pianissimo, is required for chemoattractant receptor and G protein-mediated activation of the 12 transmembrane domain adenylyl cyclase in D ictyostelium
}

\author{
Mei-Yu Chen, Yu Long, and Peter N. Devreotes ${ }^{1}$ \\ Department of Biological Chemistry, Johns Hopkins University School of M edicine, Baltimore, M aryland 21205-2185 USA
}

\begin{abstract}
Genetic analysis was applied to identify novel genes involved in G protein-linked pathways controlling development. Using restriction enzyme-mediated integration (REMI), we have identified a new gene, Pianissimo (PiaA), involved in CAMP signaling in D ictyostelium discoideum. PiaA encodes a 130-kD cytosolic protein required for chemoattractant receptor and $G$ protein-mediated activation of the 12 transmembrane domain adenylyl cyclase In piaA- null mutants, neither chemoattractant stimulation of intact cells nor GTP $\gamma$ S treatment of lysates activates the enzyme; constitutive expression of PiaA reverses these defects. Cytosols of wild-type cells that contain Pia protein reconstitute the GTP $\gamma \mathrm{S}$ stimulation of adenylyl cyclase activity in piaA- lysates, indicating that Pia is directly involved in the activation. Pia and CRAC, a previously identified cytosolic regulator, are both essential for activation of the enzyme as lysates of $\mathrm{crac}^{-} \mathrm{piaA}^{-} \mathrm{double}^{-}$ mutants require both proteins for reconstitution. Homologs of PiaA are found in Saccharomyces cerevisiae and Schizosaccaromyces pombe; disnuption of the S. cerevisiae homolog results in lethality. We propose that homologs of Pia and similar modes of regulation of these ubiquitous $\mathrm{G}$ protein-linked pathways are likely to exist in higher eukaryotes.
\end{abstract}

[Key Words: Chemoattractant receptor; G protein; adenylyl cyclase; signal transduction; Dictyostelium]

Received June 13, 1997; revised version accepted September 18, 1997.

Cells are capable of sensing their environment and al tering biological functions in response to external stimuli. In one well-known signal transduction pathway, external signals trigger the production of the second messenger CAMP. Stimulation or inhibition of adenylyl cyclase in response to extracellular signals is part of the re-pertoire of cellular regulation in diverse organisms. In mammals, for example, the enzyme is activated or inhibited in response to hormones, odorants, neurotransmitters, and chemoattractants (Gilman 1984, 1987; Levitzki 1988). The cell surface receptors that detect these stimuli possess seven transmembrane domains and are coupled to heterotrimeric G proteins (Dohlman et al. 1991). When excited, receptors activate $G$ proteins, catalyzing the exchange of GTP for GDP on the $\alpha$-subunit and the dissociation of the $\alpha$-subunit from the $\beta \gamma$-subunit complex.

The regulation of adenylyl cyclase has been the subject of extensive studies in mammalian cells. There are 10

${ }^{1}$ Corresponding author.

E-MAIL pnd@welchlink.welch.jhu.edu; FAX (410) 955-5759. different types of mammalian adenylyl cyclases ( $\mathrm{ACl}$ ACX) known to date (Sunahara et al. 1996). They share a predicted structure of 12 transmembrane segments and two large cytoplasmic domains, but differ in tissue distribution and mode of regulation. Although all eight of the isozymes characteri zed thus far are stimulated by the GTP-bound $\alpha$-subunit of $\mathrm{Gs}\left(\mathrm{G}_{\mathrm{s} \alpha}\right)$, they respond differently to coregulators. For instance, the $G$ protein $\beta \gamma$ subunit complex is a potent inhibitor of type I adenylyl cyclase but a striking stimulator of type II and type IV adenylyl cyclases (Tang and Gilman 1991). Similarly, there is type-specific regulation by $\mathrm{Ca}^{2+}$-cal modulin and protein kinases PKA and PKC (for review, see Sunahara et al. 1996).

In Dictyostelium, cAM P controls multiple stages of a developmental program triggered by depletion of nutrients, functioning as a chemoattractant, a morphogen, and an intracellular second messenger (Kay 1994; Firtel 1995; Parent and Devreotes 1996). Within a few hours after starvation, aggregation centers emerge spontaneously when the central cells within each territory begin to secrete CAMP at 6-min interval s. The periodic bursts of CAMP attract surrounding cells and also stimulate 
them to synthesi ze and secrete additional CAMP, which relays the signal distally as a propagated CAMP wave. The periodic stimulation also induces optimal expression of aggregation-specific genes. After the cells aggregate, CAMP continues to play a role within the multicellular structures as they undergo further morphogenesis to form slugs and differentiate into either stalk or spore cells in fruiting bodies.

In analogy to the hormone-activated mammalian systems, the CAMP signaling system in Dictyostelium involves surface receptor/G protein-linked signal transduction pathways (Devreotes et al. 1987, 1994). Excitation of the CAMP receptor CAR1 activates the heterotrimeric $G$ protein $\mathrm{G} 2$, leading to an elevation of intracellular CGMP (Kesbeke et al . 1988), an activation of the cytoskel etal components involved in chemotaxis (Hall et al. 1989), and an increase in the activity of the adenylyl cyclase ACA (Pitt et al. 1992). Similar to type II and IV mammalian adenylyl cyclases, ACA is activated by the $\beta \gamma$-subunit complex, rather than the $\alpha$-subunit, from G2. Structurally, ACA re sembles the mammalian adenylyl cyclases; it has two sets of predicted six transmembrane spans and two homologous cytoplasmic domains. The crystal structure of the mammalian adenylyl cyclase catalytic core has been solved recently (Zhang et al. 1997); the active site is formed jointly by cytosolic domain monomers upon dimerization. $M$ any mutations rendering ACA catal ytical ly inactive or $G$ protein insensitive (Parent and Devreotes 1995) map to a region in or adjoining the interface of the dimer.

There are differences between the regulation of ACA and its mammalian counterpart. The stimulatory effects of the $\beta \gamma$-subunit complex on type II and IV mammalian adenylyl cyclases depend on the presence of activated $G_{s \alpha}$, whereas no $G_{s \alpha}$ has been identified in Dictyostelium. ACA does not contain the GIn-X-X-Glu-Arg sequence suggested to be the $\beta \gamma$-subunit contact site (Chen et al. 1995). Unlike other effectors/regulators that interact with $\mathrm{G} \beta \gamma$-subunits, adenylyl cyclases do not have pleckstrin homology (PH) domains (Musacchio et al. 1993) but, interestingly, a PH domain-containing cytosolic protein, CRAC, is required for both receptor and GTP $\gamma S$ stimulation of ACA (Insal I et al. 1994). CRAC is translocated to membranes after chemoattractant stimulation of intact cells or during GTPyS activation of lysates; the translocation does not take place in the $\mathrm{g} \beta^{-}$ mutant (Lilly and Devreotes 1995). It has been proposed that CRAC serves as an adapter linking the $G$ protein $\beta \gamma$-subunits to activation of ACA.

Cytosolic regulators, other than calmodul in, PKC, and PKA, of mammalian adenylyl cyclases have not been reported. However, there are indications of unidentified components in adenylyl cyclase pathways. In human polymorphonuclear leukocytes (PMNs), for example, chemoattractant receptors, such as that for fM et-LeuPhe (fM LP), which are linked to $G \alpha$ i stimulate increased intracellular CAM P levels by activating adenylyl cyclase (Spi sani et al. 1996). But fM LP is incapable of stimulating the enzyme in membrane preparations (Verghese et al. 1985). Similarly, in A $9 \mathrm{~L}$ cells transfected with the $\mathrm{m} 1$ muscarinic receptor carbachol activates synthesis of
CAM P in intact cells but not in cell membranes (Fel der et al. 1989). Membrane fractions contain functionally coupled receptors, $\mathrm{G}$ proteins, and responsive adenylyl cyclase, as guanine nucleotides can regulate the binding affinity of the receptors and prostaglandin $E_{1}$ activates or $\alpha 2$-adrenergic treatment inhibits adenylyl cyclase activity.

Using insertional mutagenesis by restriction enzyme mediated integration (REMI; Kuspa and Loomis 1992), we have isolated a mutant, designated Pianissimo, that is defective in the CAMP signaling pathway. Genetic and biochemical analyses revealed that the product of the mutated gene is a cytosolic protein, distinct from CRAC. Pianissimo is required for receptor and $G$ protein-mediated activation of ACA, as is CRAC. However, our results demonstrate that Pianissimo and CRAC do not function redundantly; both proteins are integral components of the adenylyl cyclase activation pathway. Interestingly, homologs of Pianissimo are present in yeasts and we have demonstrated that the Saccharomyces cerevisiae homolog is an essential gene. It is likely that homologs of Pianissimo and similar modes of regulation of adenylyl cyclase al so exist in higher eukaryotes.

\section{Results}

Identification and isolation of the PiaA gene

To discover new genes involved in signal transduction at the early developmental stages, we isolated REMI mutants unable to aggregate on bacterial lawns. These mutants were further characterized and screened for those that failed to aggregate on non-nutrient agar plates but were abl e to express the known components of the signal transduction pathways. These mutants are likely to have specific novel defects; the mutant designated Pianissimo was among them.

We cloned the Pianissimo gene (PiaA), as described in $M$ aterials and $M$ ethods, and found the REM I insertion to be 300 bp upstream of a 3447-bp open reading frame (ORF). Extensive evidence demonstrated that the insertion was responsible for the devel opmental phenotype of the mutant. First, we linearized the rescued plasmid carrying flanking genomic fragments (pMYC32, Fig. 1A), transformed it into the wild-type cells, and recreated the mutated genomic structure by homologous recombination. The resulting cell line, MY C15, displayed the same phenotype as the original REM I mutant. We also made a knockout construct ( $P Y L 23$, Fig. 1A) within the ORF using CDNA fragments and transformed it into wild-type cells. The resulting cell line, MYC28, had the same phenotype as the original REMI mutant. Second, using cDN A fragments as the probes, we carried out N orthern bl ot analyses on RNA samples prepared from both wildtype and mutant cells at different time points of development. As shown in Figure 1B, PiaA was expressed as a 4.5-kb mRN A that, in wild-type cells, peaks between 2.5 and $5 \mathrm{hr}$ of development. There was no PiaA transcript detectable in the mutant, suggesting the cloned CDN A is the PiaA gene. Furthermore, we prepared a rabbit poly- 


\section{Chen et al.}

A.

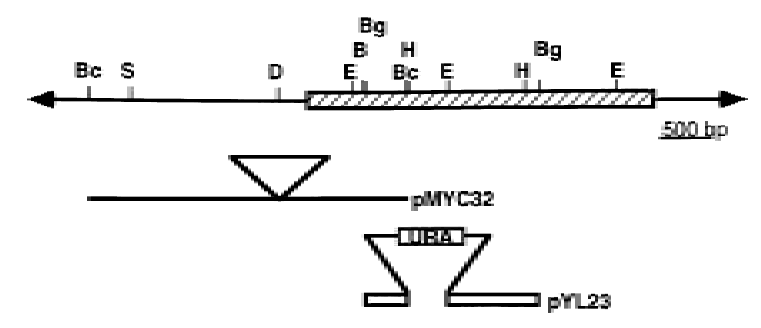

B

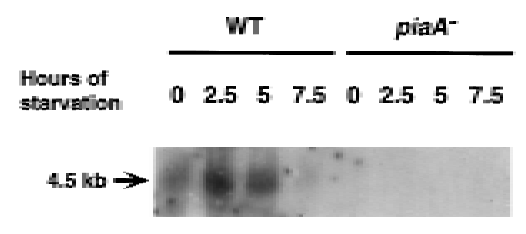

C

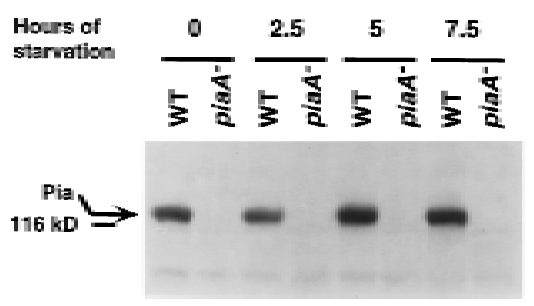

Figure 1. The structure of the PiaA gene and its expression during growth and early development. (A) Structure of the PiaA locus. The hatched box represents the PiaA coding region. (BC) Bcll; (S) Sphl; (D) Dpnll; (E) EcoRI; (Bg) Bglll; (B) BamHI; (H) HindlII. Solid lines and open bars represent genomic DNA and CDNA fragments, respectively. The plasmid pMYC 32 was rescued from the original REMI mutant using Bcll digestion (see $M$ aterials and $M$ ethods). The triangle represents the insertion of a REMI vector, pRHI30, at a Dpnll site. Plasmid pYL23 is a CDNA construct used for gene targeting; when linearized by Bglll digestion and transformed into wild-type cells, it disrupted the PiaA gene by homologous recombination, replacing $0.4 \mathrm{~kb}$ of the coding region (a HindlII-EcoRI fragment) with a vector carrying the URA selectable marker. (B) Wild-type (WT) and $\mathrm{piaA}^{-}$cells were developed in suspension and samples were taken at times indicated. RN A was prepared and separated on a $1 \%$ agarose gel containing formaldehyde, blotted, and probed with a 2.4-kb ${ }^{32} \mathrm{P}$-labeled cDN A fragment. (C) Protein samples were prepared from the same cells as in B at times indicated, separated on a 7.5\% SDS-PAGE gel, transferred onto a polyvinyldifluoride membrane, and probed with a rabbit polyclonal anti-Pia antibody.

clonal antiserum using a peptide with a 15-amino-acid sequence corresponding to the deduced carboxyl terminus of the Pia protein. As shown in Figure 1C, in growing stage wild-type cells, there is a significant amount of Pia protein. The protein level decreases slightly at $2.5 \mathrm{hr}$ of devel opment, then reaches maximum at $5 \mathrm{hr}$. There was no detectable signal in the piaA- mutant using the antiserum. In another experiment we examined the protein levels up to $32 \mathrm{hr}$ of development. We noted that the maximum level remained for $12 \mathrm{hr}$ when several degra- dation products began to show on the gel; at later time points $(16,20$, and $32 \mathrm{hr}$ ) the amount of intact protein gradually decreased and the degradation products increased. Finally, we constructed an expression vector carrying the full-length CDN A under a constitutive promoter (Act15) and transformed it into the piaA- cells. The resulting cell line, $\mathrm{PiaA} / \mathrm{piaA}^{-}$, overexpressed the Pia protein about three- to fivefold (data not shown) and was able to aggregate and make wild-type-appearing fruiting bodies (see below).

Gene expression, chemotaxis, cGMP response, and actin polymerization in the piaA ${ }^{-}$cells

One possible explanation for the failure of piaA ${ }^{-}$cel Is to aggregate during development is an inability to express an essential component of the chemoattractant receptor signaling pathway. We allowed mutant and wild-type cells to develop in suspension, with or without the addition of 50-100 nм CAMP every 6 min, and examined several components of the pathway. As shown in Figure $2 \mathrm{~A}$, although the piaA- cells accumulated less ACA or CAR1 than wild-type levels in the absence of added CAMP pulses, they accumulated similar levels when stimulated repeatedly with CAMP. The expression of $\mathrm{G} \alpha 2$ and $\mathrm{G} \beta$ in piaA-cells was al so comparable to that in wild-type cells (data not shown). Therefore, the phenotype of piaA ${ }^{-}$cells cannot be traced to a failure to express other known required genes.

To test whether the piaA ${ }^{-}$cells are able to complete the developmental program if appropriately stimulated, we performed a synergy experiment. Wild-type and piaA ${ }^{-}$cells were mixed at a 1:1 ratio and plated on nonnutrient agar. Spores from the fruiting bodies were collected into a buffer containing $10 \%$ glycerol and heated at $42^{\circ} \mathrm{C}$ for $1 \mathrm{hr}$ to eliminate possible contamination by amebae. The treated spores were diluted and plated clonally on bacteria lawns. After several days, individual plaques were scored for developmental phenotype. From a total of approximately 1600 plaques scored, 12 were found to be derived from the mutant spores, showing an aggregationless phenotype. The result demonstrates that the piaA- cells can respond to exogenous signals by expression of developmental genes necessary for spore formation, al though the efficiency of the process is reduced. Similar behavior has been observed in $\mathrm{aca}^{-}$and $\mathrm{crac}^{-}$ cells. This suggests that the defect of the piaA ${ }^{-}$cells may be, as in $\mathrm{aca}^{-}$and $\mathrm{crac}^{-}$cells, in generating CAM P signals.

Is the fail ure of piaA- cells to aggregate a result of their inability to carry out chemotaxis toward CAM P? Using cells developed in suspension for $5 \mathrm{hr}$ with repeated addition of CAMP, we performed a small-drop chemotaxis assay. In this assay, CAM P is spotted near a drop of cells on the surface of agar and after 20 min of incubation, cells are checked for movement toward the drop of chemoattractant. In 18 of 23 experiments done, piaA ${ }^{-}$cells showed a weaker chemotactic response, but in 5 experiments they responded as well as wild type (data not shown). Figure 2B shows the result of a different assay for chemotaxis. Cells developed for $5 \mathrm{hr}$ were placed on a 
A

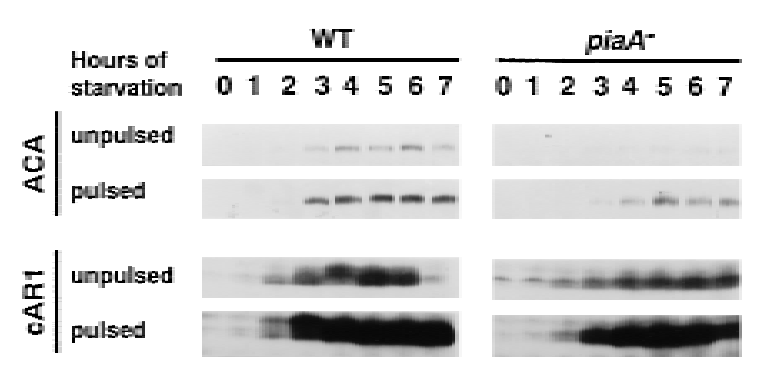

$\mathbf{B}$

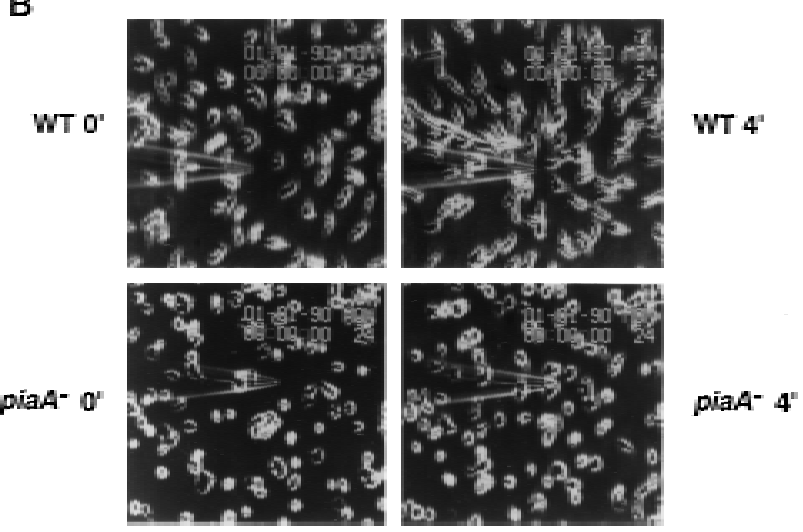

C

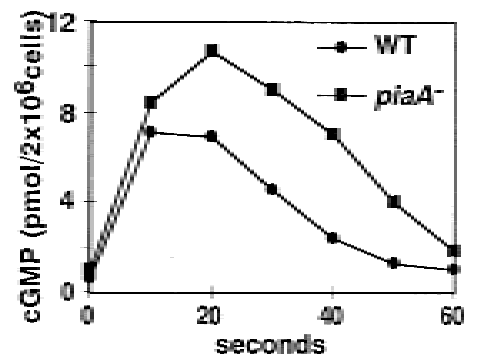

D

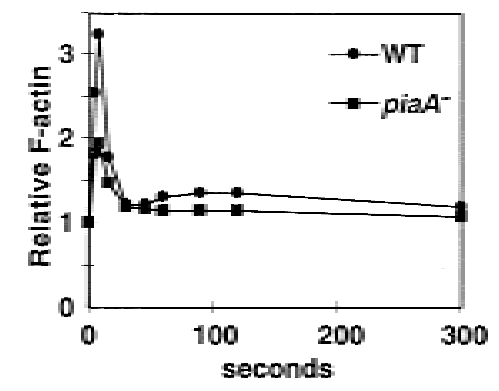

Figure 2. Gene expression, chemotaxis, CGM P production, and actin polymerization in the piaA- ${ }^{-}$cells. (A) Wild-type and piaA ${ }^{-}$cells were devel oped in suspension with or without addition of $100 \mathrm{nM}$ CAM P pulses. Samples were taken at times indicated, separated on $10 \%$ SDS-PAGE gels, and transferred onto a polyvinyldifluoride membrane. Blots were each cut horizontally, and respective halves were probed with polyclonal antisera against ACA and CAR1, respectively. (B) Wild-type and piaA ${ }^{-}$cells were developed for $5 \mathrm{hr}$ with the addition of $100 \mathrm{nM}$ CAMP at 6-min intervals. Cells were examined for chemotaxis to CAM P in a microneedle assay as described in $\mathrm{M}$ aterials and $\mathrm{M}$ ethods. At time $0 \mathrm{~min}$, a microneedle filled with cAM P solution was positioned to stimulate the cells. The response of the cells at time $4 \mathrm{~min}$ is shown on the right. (C,D) Cells were developed as in B. CAM P-induced cGM P production (C) and actin polymerization (D) were assayed as described. M eans of two to four experiments are shown.

cover slide and a microneedle filled with $100 \mu \mathrm{M}$ CAMP solution was brought to the vicinity of the cells. M utant cells within $30 \mu \mathrm{m}$ of the tip where the CAMP concentration is highest consistently responded. The wild-type cells typi cally responded from distances of $>100 \mu \mathrm{m}$, indicating a lower sensitivity in the piaA- cells. Further experiments will be required to determine whether this behavior represents a primary defect in chemotaxis (see Discussion). The positive results, however, suggest the existence of other primary defects in the piaA- ${ }^{-}$cells.

A fter $5 \mathrm{hr}$ of devel opment, piaA - cells were al so able to produce CGMP and polymerize actin in response to CAMP stimulation (Fig. $2 \mathrm{C}, \mathrm{D}$ ). The observations described above indicate that piaA ${ }^{-}$cells possess the machinery to respond to CAMP signals. However, they are unable to aggregate in pure populations. This suggests that the defect may be in the production of the CAMP signals.

PiaA is required for receptor and G protein-mediated activation of ACA

Therefore, we examined the CAMP production pathway in piaA ${ }^{-}$cells. Cells developed for $5 \mathrm{hr}$ were stimulated with a CAMP analog, 2'-deoxy-CAMP. As shown in Figure $3 A$, in wild-type cells, the accumulation of CAMP peaked at about $2 \mathrm{~min}$ after addition of the chemoattractant and then subsided. In the piaA ${ }^{-}$cells, there was no detectable activation of the enzyme in response to the stimulus. The coupling between CAR1 and $\mathrm{G} 2$ is intact in the piaA- cells as chemotaxis, cGMP response, and actin polymerization still occurred. Therefore, the inability to synthesize CAMP could be attributable to inefficient activation of a pathway linking the activated $G$ protein to ACA. We tested this possibility by assaying the activation of ACA in vitro in cell-free lysates. In this assay, GTP $\gamma$ S greatly stimulates ACA through a G $\beta$-dependent pathway (Theibert and Devreotes 1986; Wu et al. 1995). As shown in Figure 3C, GTPyS stimulated ACA activity about 13-fold in wild-type lysates, but failed to significantly stimulate the activity in piaA ${ }^{-}$lysates. However, in the presence of $\mathrm{Mn}^{2+}$ ions, which stimulate ACA directly, lysates of wild-type and piaAcells were similar, indicating that the defect in $\mathrm{piaA}^{-}$ cells does not affect the catalytic activity of the enzyme.

As stated above, expression of the full-length PiaA 
Chen et al.

Figure 3. Pia is required for receptor-mediated and GTP $\gamma$ S activation of ACA. (A) Chemoattractant receptor-mediated activation of adenylyl cyclase was assayed in 5-hr-developed wild-type, $\mathrm{piaA}^{-}$and $\mathrm{PiaA} / \mathrm{piaA}^{-}$ cells as described using $2^{\prime}$-deoxy-cAMP as the stimulus. (B) Wild-type, piaA- ${ }^{-}$, and $\mathrm{PiaA} / \mathrm{piaA}{ }^{-}$cells were devel oped on non-nutrient agar plates and photographed at $48 \mathrm{hr}$. Bar, $1 \mathrm{~mm}$. (C) Wild-type, piaA ${ }^{-}$and PiaA/ piaA ${ }^{-}$cells were developed for $5 \mathrm{hr}$ and assayed for adenylyl cyclase activity in the absence or presence of $5 \mathrm{~mm} \mathrm{MnSO}{ }_{4}$. GTP $\gamma \mathrm{S}$ stimulation was determined in the presence of $40 \mu \mathrm{M}$ GTP $\gamma S$ and $1 \mu \mathrm{M}$ CAMP in the lysate. Means of 8-10 experiments are shown.
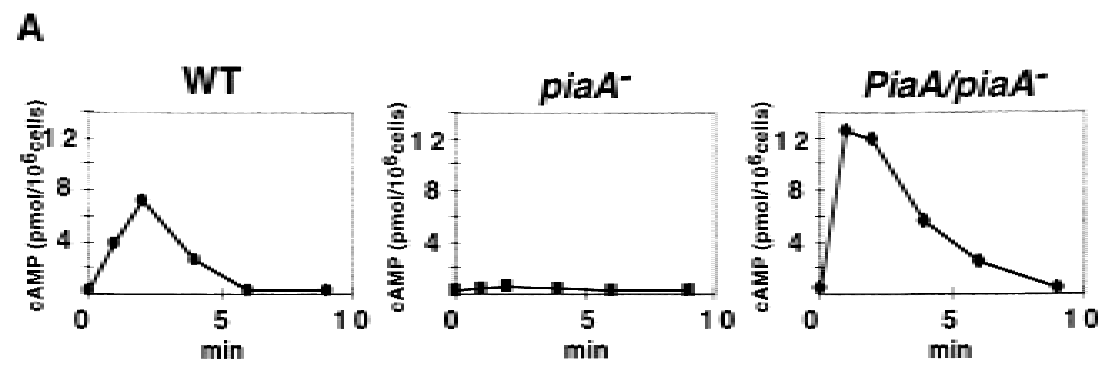

B

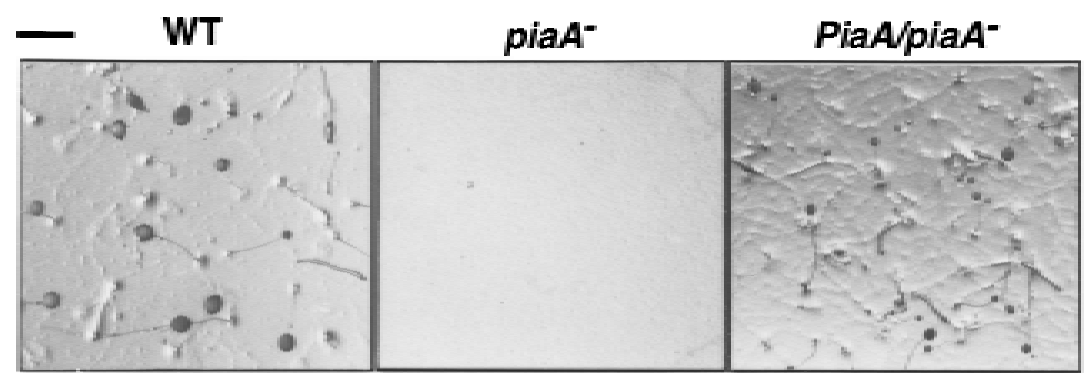

C

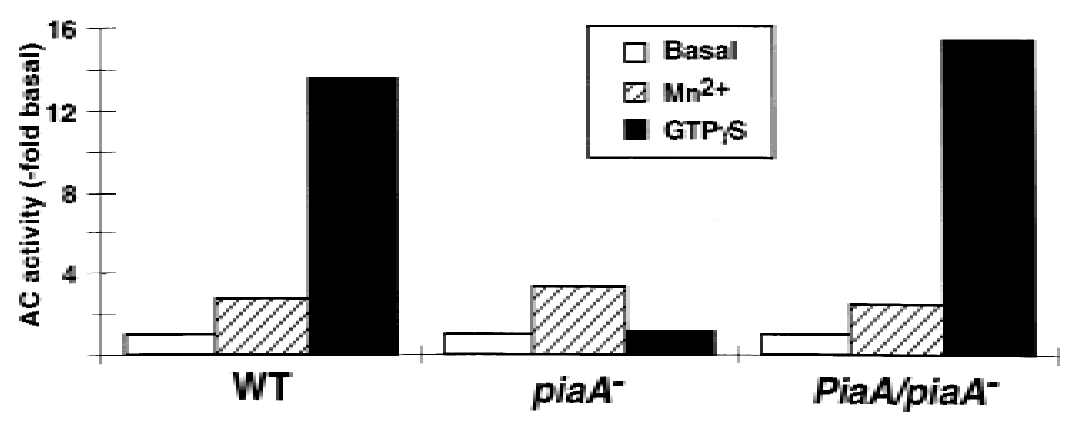

CDNA rescued the piaA ${ }^{-}$cells and the cells were able to complete the devel opmental program and make fruiting bodies (Fig. 3B). Consistently, all the biochemical defects were reversed. The rescued cell line $\mathrm{PiaA} / \mathrm{piaA}^{-}$accumulated CAMP in response to $2^{\prime}$-deoxy-cAMP stimulation with kinetics similar to those of wild-type cells (Fig. 3A). GTP $\gamma$ S stimulation of ACA activity in the PiaA/ piaA- Iysates was al so restored (Fig. $3 C$ ). These observations suggest that the fail ure of $\mathrm{piaA}^{-}$cells to aggregate is caused primarily by their inability to synthesize and secrete CAMP. The results also demonstrate that the cloned CDNA is sufficient for all of the functions of the PiaA gene.

PiaA has homologs in both S. cerevisiae and Schizosaccharomyces pombe

We sequenced the CDN A fragments, PCR fragments, and appropriate genomic fragments to assemble the fulllength sequence of the PiaA gene. The ORF encodes a protein of 1148 amino acids with a molecular mass of
$129.5 \mathrm{kD}$ (Fig. 4). The predicted protein is generally hydrophilic, with scattered short hydrophobic segments. A motif search on the sequence did not yield possible functions of the protein. We used the TBLASTN program (Altschul et al. 1990) to search the $\mathrm{N}$ ational Center for Biotechnology Information (NCBI) nonredundant databank. Two homologous sequences were found; one is SPAC $12 C 2.02 C$ in S. pombe and the other is YER093C in S. cerevisiae (accession nos. for the sequences are emb/Z54140 and gb/U 18839, respectively). Both were uncharacterized ORFs identified through genome se quencing. The $D$. discoideum PiaA gene is more homologous to the $S$. pombe gene than to the $S$. cerevisiae gene (BLAST P value of $10^{-110}$ for the $S$. pombe gene compared with $10^{-51}$ for the S. cerevisiae gene). The two yeast homologs are slightly larger (147.4 kD for the S. pombe protein and $164.4 \mathrm{kD}$ for the S. cerevisiae protein). When sequences of the three proteins are aligned, the homology is distributed throughout nearly the entire length; the size difference lies in the very amino-terminal region (Fig. 4). 
Dd -...Sp -.--- - SC MSIPHSAKQSSPLSS RRRSVTNTTPLLTPR HSRDNSSTQISSAKN ITSSSPSTITNESSK RNKQNLVLSTSFIST KRLENSAPSPTSPLM Ho

Da SC ARRTRSTMTKALINL KAEINNQYQELARLR KKKDDIEHLRDSTIS DIYSGSYSTNHLQKH SMRIRANTQLREIDN SIKRVEKHI - - - F 175 Ho

Dd SP QGENGEAKTGSTSLT RSASATVSRKSSLQE KYSTRFSYKAGCSDS CSVTVSGTGE-LIGP TRNAHSNLTPTVIQR IDFENVNEKNNSSSE 193 SC DLKQQFDKKRQRSLT TSSSIKADVGSIRND DGQNNDSEELGDHDS LTDQVTLDDEYLTTP TSGTERNSQQNLNRN STVNSRNNENHSTLS
HO

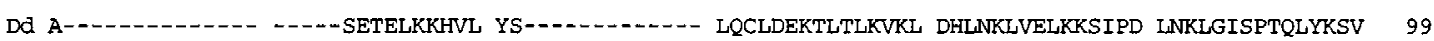
Sp DTQPNGKRPSSL--- -QSNFSQF------- ----PLLNPWLDNIY KACLEGSMKD---VI DSSNNLCEYLHEHSD PAY-AKNFSLITPTI 263 Sc IPDLDGSNKVNLTGD TEKDLGDLENENQIF TSTTTEAATWLVSDY MOSFQEKNVNPDFIA OKANGLVTLLKEHSE IRK-DLVLTSFMSSI 354 HO Dd RPFIALPPKTIRTAG LRVMR--YYLSNSNN VKELLDLKVOYFITR SLERDKHSEPERIQA LKIIRTI-----MEI DCSLMPHCFVKGLVS 182 SP LSMLELNVSEVTASV YRLLRHLFLDATAFS CCQMLNLPW-ILSKS LLSGTDAYQIEREQA FRLIRTLYFLSSTEG HEDY-LSGITRTIIS 351 SC QNLLLNGNKLIAASA YRVCR--YLINSSIF IDELLELRLDAFIII SLAKDNSFOIEREQA LKMVRFF-----IEY NNGGV-TQGIMQAIIS 436

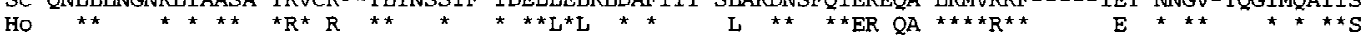

Dd IAENQEDNFCRVCLE CLTEISIRNPQISSH CGGIRTVF-DAVLDP FYQ-GIQESLLICIL YLLSDKDTRIYIRPK SDLEIILAPLTNSFN 270 Sp ICEHVSDVSRGIAVE TLIELMIIRPKILFK ANGLR-VLMISLIDG SISENLAASAALALV YLLDDPESASC CVEKPEDSLRHMALE TLLELCFVAPEMVKE CRGMR-VI-EGFLQD YTSFSLASVILDTIL QLMATHKTR--.-

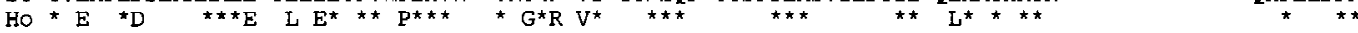

Dd IGVKLKGASKEKEKE KEKEDEVA------ --MKKWTASSKAVLT LIKSWIGIISLNSDD QGLKSVVDTLRMPQI ELQEK--ALDSIFEI 349 SP IGILLSPFTSSSSR- ---DTFNSSEEQSE QAAKAMKSSAKVASV LINSWSGLLALSTND --FQALRSIVDTLRV PSFAPRSDVIDLF-- 508

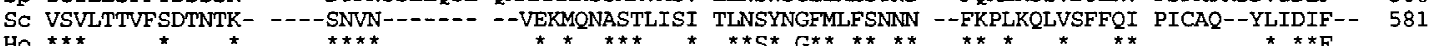

Dd FRVQLPKS------- -.---IQETFGPQRA TQTFNFGSE----TL QDLPSRTRSLRHRL- LNNYL-SVLLIAFID NGLIEGLVYLGNYVA 421 Sp --FLIFQVEYSSWSE SFLAGKRLTVVKN-- -.--QAVSNDDNINM VNIPDGS--NKKYMS LROHETAVLIFIFLE LGLVESIVCMTR--- 585 SC --LDVLKI---1--
HO ${ }_{\star \star \star *}$

Dd NRDGMSEQEKECSKN ISLKSTVLLAELLHM SNALLPPSQCAKLQT ----LPSLVNSAISF RLDPRLRSSSNTMVT NLHSYSHNK-SSTTL 506 SP -..--ASD-DPS ASRKATYLLGEVLRL -....--SDEI LPIHLGAKIQSLPSL FNMASQFTAEDRFVA TSVLQSIESLNRVKF 655 SC
HO

Dd MDSTLAIGLTGANKW RRIKGQDRRLDKVDD VKMKMEW--.....- -..---HMDDNQFQQ KIKDTQVLVTKDYQK WSWELMFELLEGPLN 582 Sp HSATQPFSQTTSLLF KEQKTD---.--- --GSFRGQRQVEHV KLKMGMQIDDSHFRS MLAETNVLATKNYYQK WRWDTLVQIMEGPLL 733

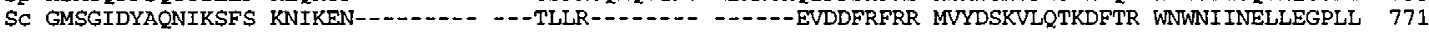

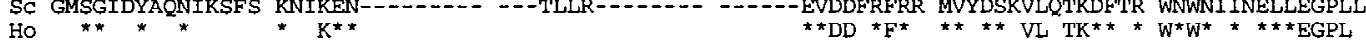

Dd NPQHLSSNTLK-TKFI KRILSFLRPNKKLFS TMAWTTE-NLKYVRT ACVALEVLISHEIGF DFLKDNKTIII-QIAD ML--KVELDYNIKPP 667 SP SPKRIDETLRTTKFM RRLLAFYKPFSNRFS SI-QNTKPNQKFIKV GCLVFRTLLANPEGV KYL-SESKVIKQIAE SLSQIDGYSEQV--- 818 SC NKRQLEELVKSTKFI RRLLVFYRPLRLRFS NVNKGAKLSQKYVQV GCQFFKTLTATPEGM KILMDDTKIIPQLAS LM--FRAMEGNI--- 856

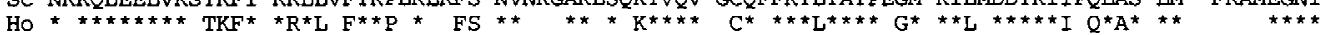

Dd PSSSSSSENKKDNVR LLNPEKVLKTMSREY FTMLGTLSSNLLGLE ILARNNIFDYIKPLA ELPGRDDLSHLIMT- -SLDYNVNGASRTIL 755 Sp --...----SEP IFSNSRLOKTLTHGY FPMLKVLSSQKEGHA IMERWRIFTTLYHLT ELRNRDDLIIIFLT- -NLDYRLEGHTRIIF 894 Sc...--- SGN IFNKNKLREKIIFGY FKFIGILTOSKNGVH ILTRWNFFTVIYKMF OFESKLGLEFLLLTI PELDLKYSSHCRVII 934

Dd QKILTSSSRVVRYLA TKYL--.---.--- --RFLLRSGVQDFSN WGVELLVQQLNDVDA KVSALSLNVLDEA-C DDPSCLEVLIDLKPN 831 Sp SKALNTGQQAVRLTA TKHLAA-----LINS ESA------NDNLNH WAISLLIFQLYDPCL EVCKTAVKVLNEVCA RNENLLAOVVQLQPS 973

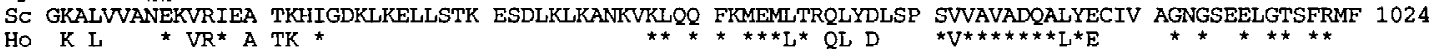

Dd LLKLGKPGKSLLLRF LSSPKGLENLLQNNG FVEQEEQLWITSENA TYVNAIES----AV- -SESLSPSVWRFKEA PDGSSTSGVYLPPHF 915 Sp LAHLGEIGSPLLLRF LATTVGFH-YLSEIN FIEHELDNWYHHRNI DYVDLLEQNFFLSFV SNLKI IDKKNNEPDE NI--------LPLHF 1054

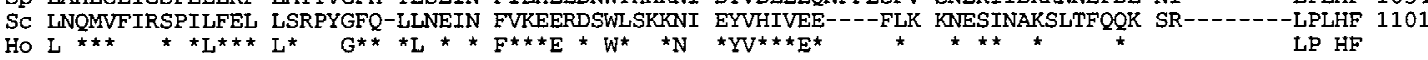

Dd FGELAKTEKGCQLIR KSNNYQRFLKITQ-- -.--.--DPTAKQ LDKRASLIAIGHIGS SVDGYSFVKESDTIK LLIGIAEKSQCLALR 994 SD YGELVKSPOGCEVLE SSGHFESFMGTLVEF YD-----KPLGNEAI ROLKSALWAIGNIGK TDOGITFLINHDTIP LIVKYAENSLIPTVR 1139 SC YESLTKTEDGILLLS QTGDLVTFMNVIKKY VNGNNMATVENAKEI LDLKAALWCVGFIGS TELGIGLIDNYSLVE DIIEVAYNASVTSVR 1191

Da STCFYALGMISCIEE AQPIFNSFGWE---S PSDLNSRILLPKDLK NSTFLSVPQYQY-- - SP GTAYFVLGLISRTSK GVEILESLHWYSLMS LMGTSQGICIPRHAG Q--VLSTPRRN---. SC FTAFYVLGLISMTRE GCEILDEMGWNCCVS VQDEPIGIALPNRLD R--FLSYNEHKWSAF GEYSDEMIVFNKSDG DLIEKCLPIEFDLDK 1279

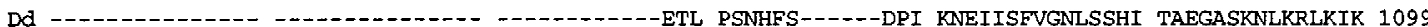

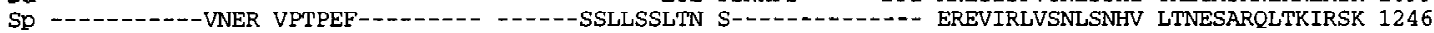
SC LLKEKDTAENPLNEK IITNKYDNDITSQTI TVSGENSSLFANEGL SSPYVTOYRNDDDSI ESKVLHIVSQLGNHI LSNHAVKEITEINNK 1369 Ho

Dd Y-PDHFATSEILNAV FILLNTFKYRLGARR FIYDLFDVAIFSSDP YHDLN---1.--- SO -NAKVFSSKRLVKAC MTILGKFHYRVQIOQ FVFELF-------PY SVLLSSSTSODLNES PSRPNNLSISA 1309 SC YGPRLFENEKMFFKV FNMMSKYRFKPHVRK FLCGLF------IN NRALENVIRID-NKR DKRPANFTR-- 1430

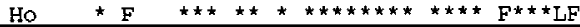

Figure 4. Amino acid sequences of Dictyostelium Pia and two yeast homol ogs. The al ignment of three sequences is shown. N umbers on the right indicate amino acid positions. (Dd) Dictyostelium; (Sp) S. pombe; (Sc) S. cerevisiae; (Ho) homology between sequences. Residues identical in all three homologs are indicated by letters. Residues similar in all three homologs are indicated by an asterisk. Residues identical or similar in two sequences only are not marked. Segments identified by TM AP are underlined (see text for details). 


\section{Chen et al.}

We have performed a computer analysis on the multiple sequence alignments using the TMAP algorithm (Persson and Argos 1994; Milpetz et al. 1995) and the results predict that all three proteins have a transmembrane segment (residues 387-415 in the D. discoideum Pia; see Fig. 4). The membrane localization is proven wrong for the D. discoideum Pia (see bel ow), whereas the localization for the two yeast proteins remains to be determined. If the yeast proteins are also cytosolic, the transmembrane segments predicted by TMAP may simply indicate a buried hydrophobic region common in all three proteins.

\section{PIA1 is an essential gene in S. cerevisiae}

We disrupted the homologous gene PIA 1 in S. cerevisiae by using the deletion technique of Lorenz et al. (1995) (Fig. 5A; see $M$ aterials and $M$ ethods). A wild-type diploid Trp auxotroph was transformed with a PCR fragment consisting of the TRP1 marker and $40 \mathrm{bp}$ of sequence homology to the regions upstream of the $5^{\prime}$ end and downstream of the $3^{\prime}$ end of the PIA1 gene and Trp ${ }^{+}$ colonies were selected. The heterozygous pial deletion strain (YMC1; pia1 1 ::TRP1/PIA 1), as verified by both PCR analysis and Southern blotting, was sporulated. The resulting asci were dissected and the spore viability was determined. Among the 21 sets of tetrads analyzed, 9 gave rise to one and 12 produced two viable colonies. An exampleis shown in Figure 5B. Subsequent plating found all the viable colonies to be trp ${ }^{-}$. This result indicates that the deletion of PIA 1 is lethal and that PIA1 is an essential gene in S. cerevisiae. The spots on the tetrad dissection plate where no gross colonies formed contained microcolonies formed by clusters of cells. This observation argues against the possibility that the PIA1 gene is required for germination.

\section{Reconstitution of GTP $\gamma$ S activation of adenylyl cyclase in piaA-Iysates}

To further define the function of the $\mathrm{D}$. discoideum Pia protein, we performed a crude subcellular fractionation to localize the protein. Cells were lysed by passage through a $5-\mu \mathrm{m}$ nucleopore filter and the lysates were analyzed by differential centrifugation. The particulate and soluble fractions were analyzed by SDS-PAGE and Western blot analysis with a carboxy-terminal antiserum of Pia. As shown in Figure $6 \mathrm{~A}$, the protein was located quantitatively to the soluble fraction. This finding immediately raised the possibility that the defect in GTP $\gamma S$ stimulation of ACA in piaA- lysates might be reconstituted by the addition of supernatants containing Pia protein. To test this possibility, various supernatants or buffer were added into lysates prepared from piaA ${ }^{-}$ cells in the presence of GTP $\gamma S$ and ACA activity was assayed after a short incubation. As shown in Figure 6B, neither the buffer nor the supernatants prepared from piaA- cells corrected the defect, whereas supernatants prepared from either wild-type cells or $\mathrm{PiaA} / \mathrm{piaA}{ }^{-}$cells did. This suggests that the Pia protein acts as a cytosolic activator of adenylyl cyclase.

The function of the Pia protein in conferring GTP $\gamma S$ stimulation of ACA is not redundant with that of the

A
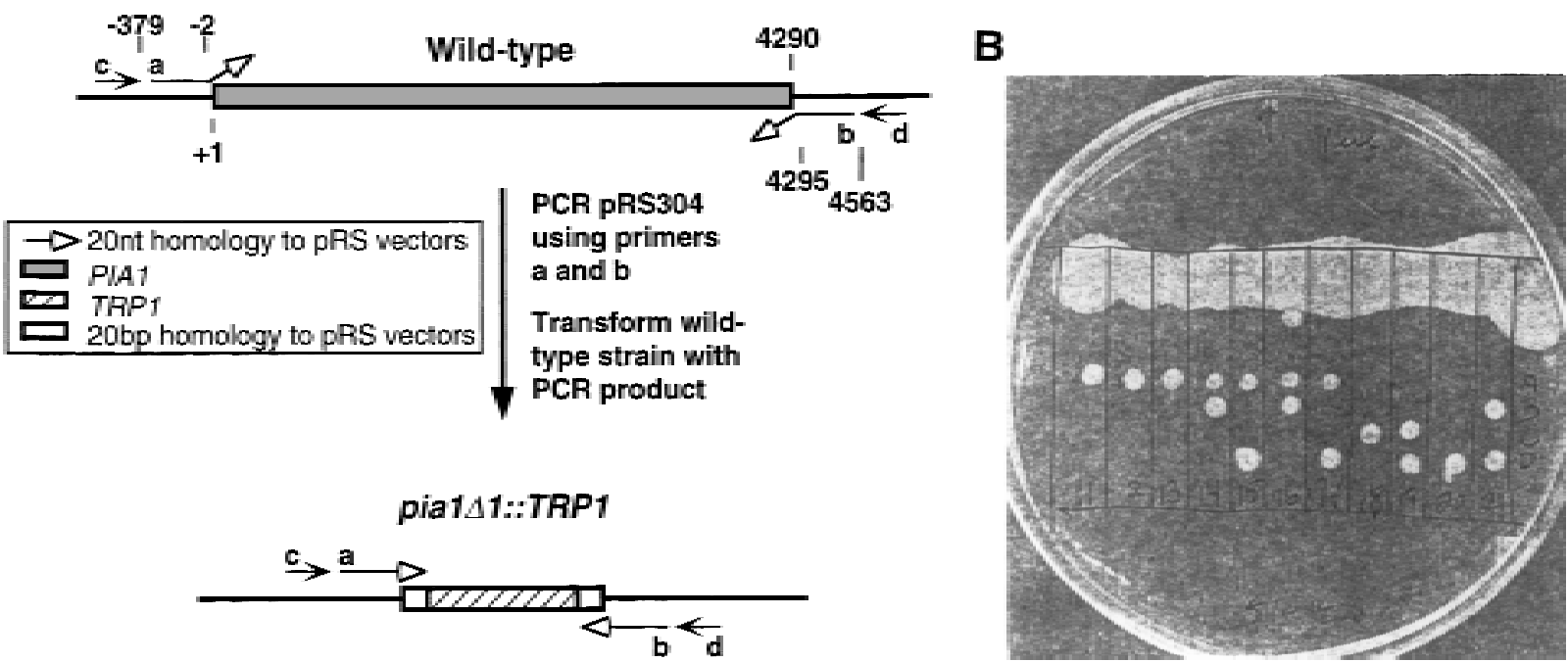

Figure 5. Disruption of the S. cerevisiae PIA 1 gene results in lethality. (A) A schematic diagram of the disruption of the PIA 1 gene. $\mathrm{N}$ umbers indicate nucl eotide positions. Primers $\mathrm{a}$ and $\mathrm{b}$ were both 60 nucl eotides in length; each contai ned 40 nucl eotides homol ogous to the locus, and 20 nucl eotides homologous to pRS (indicated by open arrows). These two primers were used to amplify the TRP1 gene from pRS304 and the PCR product was transformed into a wild-type strain. The 40-bp region flanking TRP1 allowed homologous recombination at the PIA 1 locus and del etion clones were first identified by PCR analysis (using primers a and $d$ or primers $b$ and $c$ ), then verified by Southern blot analysis (probed with oligonucleotide $\mathrm{C}$ ). (B) The heterozygous pial del etion strain was sporulated and the tetrads were dissected by micromanipulation. The four spores from individual asci were aligned vertically and allowed to germinate on a YPD plate at $30^{\circ} \mathrm{C}$. The picture was taken 5 days after dissection. 
A

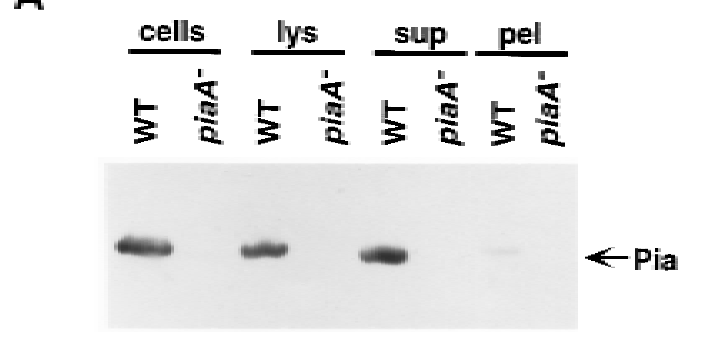

B

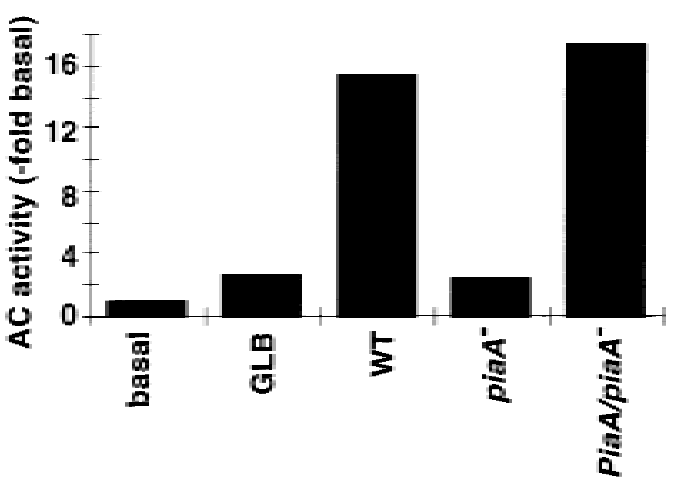

C

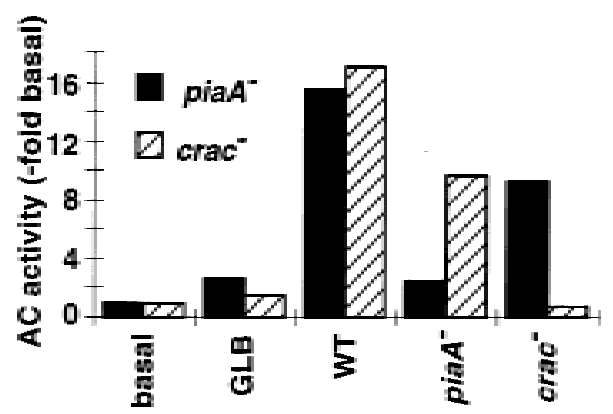

D

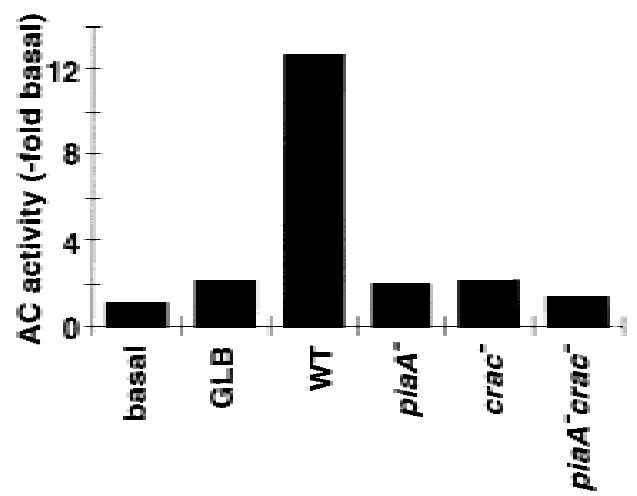

Figure 6. Reconstitution of GTP $\gamma$ S activation of ACA in mutant lysates. (A) Protein samples of whole cells (cells), filter lysates (lys), soluble (sup), and particulate (pel) fractions of lysates were separated on a $6 \%$ SDS-PAGE gel, blotted and probed with a rabbit antiserum directed against the carboxyl terminus of the Pia protein. Each lane was loaded with a sample equival ent to $4 \times 10^{6}$ cells. (B) Reconstitution of GTPyS activation of ACA in piaA- lysate was performed, as described in Materials and Methods, on cells devel oped for $5.5 \mathrm{hr}$, using buffer (GLB) or supernatants prepared from different cell lines as indicated. Basal activity was assayed in the absence of GTP $\gamma$ S. M eans of three to four experiments are shown. (C) Reconstitution of GTP $\gamma S$ activation of ACA in Iysates prepared from $\mathrm{piaA}^{-}$or $\mathrm{Crac}^{-}$cells. Buffer or supernatants from different cell lines were added as indicated. Shown are means of three

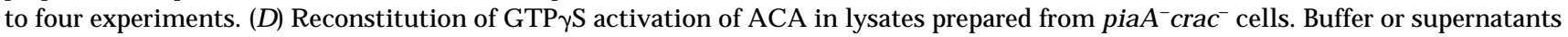
from different cell lines were added as indicated. Means of two to four experiments are shown.

previously identified cytosolic regulator of adenylyl cyclase CRAC. As shown in Figure 6C, the supernatants from $\mathrm{crac}^{-}$cells reconstituted piaA ${ }^{-}$Iysates significantly and supernatants from piaA ${ }^{-}$cells reconstituted $\mathrm{crac}^{-}$ Iysates significantly. The activity of either protein in cytosols does not depend on the presence of the other protein. This suggests that both of these proteins are integral components of the pathway leading to activation of ACA; the conclusion is further supported by the observation presented in Figure 6D. We prepared a cell line lacking both the Pia and CRAC proteins by knocking out the PiaA gene in $\mathrm{Crac}^{-}$cel Is (see $\mathrm{M}$ aterials and $M$ ethods). Lysates from this piaA ${ }^{-} \mathrm{Crac}^{-}$double knockout cell line were prepared and various supernatants added to test for reconstitution activity. Although wild-type supernatant was able to reconstitute GTP $\gamma$ S stimulation of ACA, supernatants lacking either one of the cytosolic regulators were ineffective.

\section{Discussion}

The discovery of the Pia protein identifies a second cy- tosolic regulator of adenylyl cyclase ACA. Pia and the previously identified cytosolic regulator CRAC have several common features. They both seem to act downstream of receptor/G protein coupling. Responses requiring CAR 1/G2 interaction, such as CAM P-induced CGMP production and actin polymerization, can be measured in $\mathrm{Crac}^{-}$(Insall et al. 1994) and piaA- mutants. However, chemoattractant receptor activation of ACA in vivo and GTP $\gamma$ S activation of ACA in vitro are completely absent in both mutants. Furthermore, GTP $\gamma S$ activation of ACA in lysates prepared from either $\mathrm{Crac}^{-}$or piaA cel Is can be reconstituted by providing supernatants containing the appropriate missing protein. N evertheless, Pia and CRAC do not function redundantly in activating adenylyl cyclase; both are needed for responses to CAM P or GTP $y$ S. Data from reciprocal reconstitution experiments and reconstitution of piaA ${ }^{-} \mathrm{Crac}^{-}$lysates al so suggest that both Pia and CRAC are components in the activation pathway, not that one is controlling the expression of the other.

Figure 7 shows a schematic model of the activation of ACA. Because the other components of the adenylyl cy- 


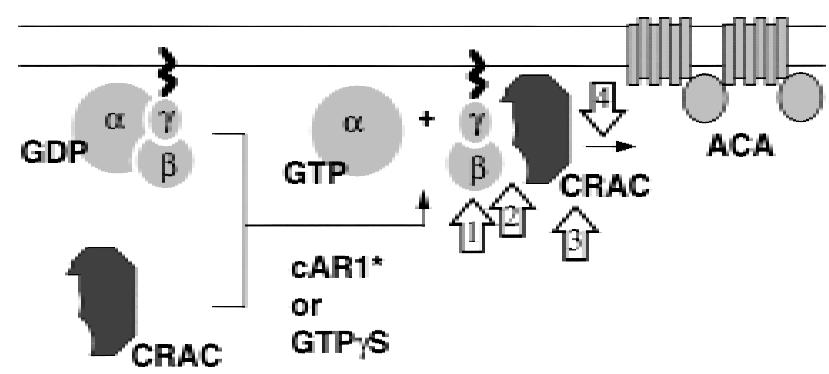

Figure 7. A schematic model of activation of ACA. The double lines represent the plasma membrane. CAR ${ }^{*}$ represents the activated surface receptor. U pon receptor or GTP $\gamma S$ activation, CRAC translocates onto the membrane. The binding of CRAC to the membrane is a $\mathrm{G} \beta$-dependent process. Open arrows indicate possible points of action of Pia. See Discussion for details.

clase activation system are membrane proteins, it is expected that the cytosolic regulators somehow interact with the membrane for activation to occur. This is the case for CRAC. During receptor or GTP $\gamma$ S-mediated activation of $A C A$, there is an increase in the amount of CRAC that cosediments with membranes (Lilly and Devreotes 1995). The association of CRAC with membranes is time and GTP $\gamma$ S dependent and correlated with the activation of ACA. The binding of CRAC to membranes does not depend on CAR1, G $\alpha 2$, or ACA, but in cells lacking the $G \beta$ subunit it does not occur, suggesting either that $\beta \gamma$-subunits serve as CRAC-binding sites or are required for their generation. In prel iminary experiments, negligible amounts of Pia have been observed to translocate to the membranes (M.-Y. Chen and P.N. Devreotes, unpubl.). Therefore, Pia is unlikely to be the CRAC-binding site. Pia may participate in the activation, beyond GTP $\gamma$ S binding and subunit dissociation, of the $G$ protein (open arrow 1 in Fig. 7). Pia may be required in the generation of CRAC sites or act on G $\beta \gamma$ (open arrow 2 in Fig. 7) to facilitate the transl ocation of CRAC. Alternatively, optimal activation may require some interaction between Pia and CRAC (open arrow 3 in Fig. 7). Or Pia may act after CRAC has bound to the membranes (open arrow 4 in Fig. 7). We have developed an assay to separate the step involving GTP $\gamma S$ activation from that of CRAC binding and shown that CRAC can act after the removal of GTP $\gamma$ S (Lilly and Devreotes 1995). Using this assay and the piaA ${ }^{-} \mathrm{Crac}^{-}$double knockout cells, we should be able to test the above possibilities.

Genetic analysis suggests that the pathway leading from surface receptor to the activation of adenylyl cyclase involves further regulatory steps. Other than the two cytosolic regulators, two additional genes, ERK 2 and AleA, are al so involved in the activation of ACA (Segall et al. 1995; Insall et al. 1996). ERK2 is a mitogen-associated protein (MAP) kinase and AleA is a homolog of the yeast CDC25 gene, a Ras exchange factor (RasGEF). The erk $2^{-}$and aleA ${ }^{-}$mutants are phenotypically similar to the piaA ${ }^{-}$and $\mathrm{Crac}^{-}$mutants in that they are specifically defective in receptor/G protein-mediated activation of
ACA. It is not yet known whether ERK2 and Ale act directly in the activation pathway; attempts to reconstitute the GTPyS stimulation of ACA in lysates from these two mutants have not been successful (B.J. Blacklock and P.N. Devreotes, unpubl.). Recently, ERK2 has been shown to be activated transiently by chemoattractants ( $M$ aeda et al. 1996). It remains to be determined whether ERK2 acts on, for instance, G protein $\beta \gamma$-subunits, ACA, CRAC, or Pia. We have noted that supernatants prepared from erk $2^{-}$or al $\mathrm{eA}^{-}$cells can reconstitute lysates prepared from piaA ${ }^{-}$or $\mathrm{crac}^{-}$cells in GTP $\gamma \mathrm{S}$ activation of adenylyl cyclase (M.-Y. Chen, B.J. Blacklock, and P.N. Devreotes, unpubl.), indicating that Pia and CRAC proteins are present in the erk $2^{-}$and aleA ${ }^{-}$cells.

Whether piaA ${ }^{-}$cells have a primary chemotaxis defect requires further investigation. In the chemotaxis assay using microneedles, the response in the mutant was much weaker than that in wild-type cells. However, it was clearly a positive response when compared to $\mathrm{g}^{-}$ cells, which are unable to carry out chemotaxis to any chemoattractant. The intermittent positive results from small-drop assays also demonstrate the ability of the cells to move toward the CAMP source. It is noted that another adenylyl cyclase pathway mutant, aleA-, also exhibits very weak chemotactic response (Insall et al. 1996). This may indicate that the pathways leading to activation of adenylyl cyclase and chemotaxis are intertwined and share common components or that intracellular CAMP somehow modulates the chemotaxis response.

Chemoattractants lead to many responses, besides activation of adenylyl cyclase, in Dictyostelium (Devreotes and Zigmond 1988; Caterina and Devreotes 1991; Chen et al. 1996). Evidence suggests that a single $G \beta$ is required for most of the $\mathrm{G}$ protein-mediated responses in D. discoideum. The variety of $\mathrm{G} \alpha$ subunits may serve to specify the activation of the $\beta \gamma$-subunit complex by different chemoattractant receptors. The unique $\mathrm{G} \beta$ senses signals from different chemoattractant receptors and is a major transducer of signals to different effectors. For example, $G \alpha 2$ and $G_{\alpha} 4$ subunits are responsible for the coupling of the release of $\beta \gamma$-subunits to CAR 1 and the folic acid receptor, respectively (Kesbeke et al. 1988; Hadwiger et al. 1994). The $\mathrm{g}^{-}{ }^{-}$cells respond to neither CAM P nor folic acid; receptor-mediated adenylyl cyclase, guanylyl cyclase, phospholipase C (PLC) activation, and actin polymerization are all absent (Wu et al . 1995). The signal ing pathways leading to different effectors seem to branch at $\mathrm{G} \beta$ because mutants defective in activation of one specific effector exist. There are nonchemotactic mutants, such as KI8 and KI10 obtained from chemical mutagenesis, defective in CAMP-induced activation of guanylyl cyclase but not the activation of adenylyl cyclase and PLC (Kuwayama et al. 1993). Mutants $\mathrm{Crac}^{-}$, aleA ${ }^{-}$, erk $2^{-}$, and piaA ${ }^{-}$are all specifically defective in CAM $P$ activation of adenylyl cyclase, whereas the CGM P response to CAMP stimulation is still present in these mutants. This indicates that the blockade in the signaling pathway in these mutants resides downstream of $\mathrm{G} \beta$ and specifically in the branch of the pathway leading to 
ACA. How are these multiple proteins involved in activating the same enzyme? Do they act sequentially in the pathway or do they form a complex and act simultaneously? Further biochemical analyses should help to answer these and other questions.

The target of Ale is likely to be a Ras-like protein. Several Ras genes have been identified in Dictyostelium, but little is known about the function of Ras proteins in D. discoideum. Whether there is a Ras pathway interacting with and modulating the adenylyl cyclase activation pathway in D. discoideum is currently under investigation. Interestingly, Ras proteins and CDC25 gene product are controlling elements of the adenylyl cyclase system in the yeast S. cerevisiae (Broek et al . 1985; Toda et al. 1985). RAS1 and RAS2 proteins regulate this adenylyl cyclase in a GTP-dependent manner (Toda et al . 1985). Ras activity is controlled by IRA 1/IRA 2 (GT Pase activating proteins; Tanaka et al. 1990) and CDC25/ SCD25 (nucleoti de exchange factors; Crechet et al. 1990; Jones et al. 1991). The Ras/cyclase pathway regulates a range of cellular events, including cell growth, glycogen metabolism, cell cycle progression, and heat shock sensitivity (Thevelein 1992). Haploid spores of S. cerevisiae lacking adenylyl cyclase give rise to microcolonies and haploid spores lacking both RAS1 and RAS2 genes are not viable (Wigler et al . 1988). The phenotype of S. cerevisiae PIA1 deletion mutant is reminiscent of that of adenylyl cyclase pathway mutants; further experiments are required to determine whether the $\mathrm{S}$. cerevisiae Pia protein is involved in this pathway.

The S. pombe adenylyl cyclase, not regulated by Ras (N adin-Davis et al. 1986), is likely regulated by a heterotrimeric $\mathrm{G}$ protein-linked pathway as the $\mathrm{G} \alpha$ subunit encoded by the GPA2 gene is involved in the determination of the CAMP level according to nutritional conditions (Isshiki et al. 1992). In S. pombe, the FBPI gene, encoding fructose-1,6-bisphosphatase, is repressed transcriptionally by glucose and this glucose repression involves a CAM P signaling pathway. Genetic and molecuIar analyses of FBP1 transcriptional regulation have led to the identification of 1 GIT (glucose-insensitive-transcription) genes (Hoffman and Winston 1990). Amonong these 10 genes, GIT2 encodes an adenylyl cyclase (Hoffman and Winston 1991) and GIT8 is the GPA2 gene (N ocero et al. 1994); the rest of the GIT genes are likely to encode components of the CAMP signal transduction pathway in S. pombe. It will be interesting to see whether the S. pombe PIA homolog gene is one of the other GIT genes.

It is intriguing that $\mathrm{PiaA}, \mathrm{a} \mathrm{D}$. discoideum regulator of adenylyl cyclase, has homologs in yeasts, where the structure and regulation of the adenylyl cyclases appear to be very different (Kataoka et al. 1985; YamawakiKataoka et al . 1989; Young et al. 1989). It is possible that certain subtypes of adenylyl cyclase in mammals are regulated by a similar pathway involving cytosolic regulators. But it is perhaps more likely that the Pia genes play some more fundamental role. Our studies position the site of action of PiaA between the G protein $\beta \gamma$ subunits and the enzyme, perhaps in regulation or modi- fication of the $\beta \gamma$-subunits. In yeasts, the Pia pathway targets effectors involved in lethality; it will be interesting to determine whether heterotrimeric $G$ proteins are involved in this pathway. Further studies, such as cloning of mammalian PiaA homologs and yeast proteins interacting with $\mathrm{Pia}$, are required to address these questions.

\section{Materials and methods}

Dictyostelium growth, development, and transformation

D. discoideum strains were grown axenically in HL5 medium (Sussman and Sussman 1967) with appropriate selection at $22^{\circ} \mathrm{C}$. Development of cells in the development buffer (DB) $(5$ mM N a $\mathrm{HPO}_{4}, 5 \mathrm{mM} \mathrm{KH}_{2} \mathrm{PO}_{4}, 2 \mathrm{~mm} \mathrm{MgSO} 4,0.2 \mathrm{~mm} \mathrm{CaCl}_{2}$ ) was done as described (Devreotes et al. 1987). Transformation of cells with DN A was performed essentially as described (Howard et al. 1988).

\section{Cloning of Dictyostelium PiaA}

Molecular cloning procedures were performed essentially as described (Sambrook et al. 1989), unless otherwise noted.

The initial step of cloning the PiaA gene was to isolate the genomic DNA flanking the REMI vector. Genomic DNA was isolated as described (Sun et al. 1990) from the REMI mutant and digested with Bcll, an enzyme that does not cut in the inserted REMI vector. Subsequent DN A ligation and transformation into Escherichia coli were performed essentially as described (Kuspa and Loomis 1992). Transformants, carrying the rescued plasmid pMYC32 (Fig. 1A), were selected on ampicillin plates.

Three rounds of CDNA walks were performed in a $\lambda$ gt11 Dictyostelium cDN A library, using a digoxiginin (DIG)-labeled genomic fragment obtained from pMYC32 as the probe for the first round of screening. DIG labeling was done by using the Genius nonradiolabeling system (Boehringer Mannheim) according to the protocol of the manufacturer. Inserts of Iambda clones were subcloned and sequenced. A cDN A contig of $3.5 \mathrm{~kb}$ was assembled according to restriction maps and partial sequences of these fragments. Complete sequence analysis of this 3.5-kb contig revealed a partial ORF, missing its $5^{\prime}$ portion.

To obtain DNA fragments containing the start codon, we performed PCR amplifications on a pACTII Dictyostelium cDN A library (a kind gift of Dr. Adam Kuspa, Baylor College of Medicine, Houston, TX). Primary amplifications were done using the library as the template, an antisense oligonucleotide (antiE; 5'-TGAGATCTCTGTTAGACATTCAAGAC), and an oligonucleotide carrying vector sequence (L1736; 5'-CTATCTATTCGATGATG) as the primers. Secondly, amplifications on the products of primary amplifications were done using a more $5^{\prime}$ (when compared with antiE) antisense primer (antiF; 5 '-GCTTGAATTCTTTCAGGTTCTGAATG) and the same vector primer. We subcloned the products of the secondary PCR amplifications and sequenced three clones. Sequences of the three clones differ slightly in the very 5 ' region yet they share an in-frame start codon. This initiation codon was verified by sequences from relevant genomic fragments.

Full-length cDNA clones were constructed by splicing together CDNA fragments and the 5' PCR fragments using convenient restriction sites.

Construction of cell lines

piaA-cells The original REMI piaA- mutant, HM 440 (a kind 
gift of Dr. R. Kay, Medical Research Council, Cambridge, UK) was generated by DpnII REM I of pRHI30 (Insall et al. 1996) into $\mathrm{DH} 1$, a uracil axotroph strain derived from $\mathrm{AX} 3$ by del eting the entire pyr5-6 sequence. Two knockout constructs, pM YC 32 and pYL23 (Fig. 1A), were used to create the piaA ${ }^{-}$mutants MYC15 and MYC28, respectively, by homologous recombination. Briefly, pMYC 32 was linearized by Bcll or pYL23 by Bglll digestion and transformed into $\mathrm{DH} 1$; uracil prototrophs were selected in FM medium with no uracil supplement. Genomic DNA was isolated from $\mathrm{Ura}^{+}$clones and digested with Bcll or BglII, respectively. Southern analysis was performed using appropriate DIG-labeled CDNA fragments as the probes to verify the disruption of PiaA locus. Both MYC15 and MYC28 cells were used in further characterizations.

PiaA/piaA- cells The full-length cDNA of PiaA was inserted into the Dictyostelium integrating expression vector pB18 (Johnson et al. 1991) in a sense orientation. The resulting plasmid was transformed into the piaA- cells; transformants were selected in HL5 plus $20 \mu \mathrm{g} / \mathrm{ml}$ of G418. The expression of the Pia protein was verified by Western blot analysis with an antibody directed against the carboxyl terminus of Pia (see below).

piaA ${ }^{-} \mathrm{Crac}^{-}$cells The PiaA gene was disrupted in the previously existing $\mathrm{crac}^{-}$cell line BB1 (obtained from B. Blacklock, this laboratory) by gene targeting. The disruption construct, pYL44, was similar to pYL23 (Fig. 1A), except that the URA fragment was replaced with a blastocidin-S resistance gene expression cassette (1.4-kb EcoRI-Xbal fragment from $\mathrm{pJH} 280$, a kind gift of Dr. Jeffrey A. Hadwiger, Oklahoma StateU niversity, Stillwater). The plasmid pYL44 was linearized and electroporated into BB1; transformants were selected in HL5 plus $10 \mu \mathrm{g} /$ $\mathrm{ml}$ of blastocidin $\mathrm{S}$ and the disruption of PiaA locus was verified by PCR and Southern blot analyses.

\section{Northern and Western blot analyses}

Total cellular RNA was prepared from either growing cells or cells developed in suspension using catrimox-14 (Dahle and M acfarlane 1993) (Iowa Biotech Corp., no. IBC 010) as described (Insall et al. 1996). Forty micrograms of total RNA for each time point was electrophoresed on a formaldehyde-containing $1 \%$ agarose gel, transferred to Hybond- $\mathrm{N}+$ membrane (Amersham), and fixed by baking at $80^{\circ} \mathrm{C}$ for $2 \mathrm{hr}$. A ${ }^{32} \mathrm{P}$-labeled 2.4-kb PiaA CDNA fragment (BamHI-Xbal) was used as the probe. Prehybridization and hybridization were carried out at $42^{\circ} \mathrm{C}$ in $50 \%$ formamide, $10 \%$ dextran sulfate, $1 \mathrm{M} \mathrm{N} \mathrm{aCl}, 1 \%$ SDS, and 250 $\mu \mathrm{g} / \mathrm{ml}$ sonicated salmon sperm DNA for $1 \mathrm{hr}$ and overnight, respectively. After hybridization, the filter was washed in $2 x$ SSC, $0.1 \%$ SDS at room temperature for $15 \mathrm{~min}$; in $2 \times \mathrm{SSC}$, $0.1 \%$ SDS at $60^{\circ} \mathrm{C}$ for $15 \mathrm{~min}$; and twice in $0.2 \times \mathrm{SSC}, 0.1 \%$ SDS at $65^{\circ} \mathrm{C}$ for $15 \mathrm{~min}$.

Whole cell protein samples from either growing or developed cells were prepared by resuspending cell pellets in SDS sample buffer. Fractions of lysates were prepared by first forcing the cell suspension at a density of $8 \times 10^{7} \mathrm{cells} / \mathrm{ml}$ in glycerol lysis buffer [GLB; $10 \mathrm{~mm}$ Tris- $\mathrm{HCl}(\mathrm{pH} 8), 1 \mathrm{~mm} \mathrm{MgSO}_{4}, 0.2 \mathrm{~mm}$ EGTA, and $10 \%$ glycerol ] through a 5- $\mathrm{mm}$ nucleopore filter and then centrifuged the lysates at $12,000 \mathrm{rpm}$ in a SS34 rotor at $4^{\circ} \mathrm{C}$ for $30 \mathrm{~min}$ or $36,000 \mathrm{rpm}$ in a SW60 rotor at $4^{\circ} \mathrm{C}$ for $1 \mathrm{hr}$. Both supernatants and pellets were collected and GLB was used to resuspend the pellets. Protein samples were separated by SDSPAGE and transferred onto the Immobilon-P membrane ( $\mathrm{M} \mathrm{illi-}$ pore). $C A R 1, G \alpha 2, G \beta$, and ACA were probed with polyclonal antisera, as previously described (Chen et al. 1994; Klein et al. 1988; Lilly et al. 1993; Parent and Devreotes 1995). Pia was probed with a polyclonal antiserum raised against a peptide $\left(\mathrm{H}_{2} \mathrm{~N}\right.$-CFDVAIFSSDPY HDLN-COOH) corresponding to the carboxy-terminal sequence of Pia protein. The peptide was coupled to BSA using the Inject Activated Immunogen Conjugation kit (PIERCE) according to the protocol of the manufacturer and used to immunize a rabbit.

\section{Disruption of PiaA homolog in S. cerevisiae}

The pial mutant strain was generated using the PCR-mediated gene deletion technique previously described (see Fig. 5A; Lorenz et al. 1995). In brief, two PCR primers, each 60 nucleotides in length, were synthesized. Primer a (5'-CTTCGTGCTGTACCGCTTCTATTAAGTTTTTGAAATTCACAGATTGTACTGAGAGTGCAC) consists of 40 nucl eotides of sequence homologous to the region upstream of the start codon of PIA 1 , followed by 20 nucleotides of sequence homologous to the pRS series of yeast shuttle vectors. Primer b (5'-ATTGTGACTATATACATTTATACATGCGGCCCTTTTTTGCCTGTGCGGTATTTCACACCG) consists of 40 nucleotides of sequence homologous to the region downstream of the stop codon of PIA 1, followed by 20 nucleotides of sequence from the opposing side of the selectable marker within the pRS vectors. The two primers were used in PCRs to amplify the TRP1 marker from one of the pRS vectors, $\mathrm{pRS304}$. PCRs were performed using the following cycling protocol: one cycle for $3 \mathrm{~min}$ at $94^{\circ} \mathrm{C}$; 35 cycles of $1 \mathrm{~min}$ at $94^{\circ} \mathrm{C}, 2 \mathrm{~min}$ at $55^{\circ} \mathrm{C}, 3 \mathrm{~min}$ at $72^{\circ} \mathrm{C}$; followed by one cycle of $8 \mathrm{~min}$ at $72^{\circ} \mathrm{C}$. The PCR product consists of linear double-stranded DNA containing the selectable marker TRP1 and $40 \mathrm{bp}$ of sequence homologous to the region flanking the PIA 1 locus. After phenol/chloroform extraction and ethanol precipitation, this PCR product was transformed into diploid SM 1060 (MATa/ $\alpha$ can1/can1 his4/his4 leu2/leu2 trp1/trp1 ura3/ura3) yeast cells by the lithium acetate procedure (Ito et al. 1983). Homologous recombination replaced the PIAI locus with the TRP1 marker. Trp ${ }^{+}$clones were colony-purified and genomic DNA was isolated from them. PCR amplifications on the genomic DN A using diagnostic primer sets (primers a and $d$ or primers $b$ and $c$; see Fig. 5A) were performed. The sequences of the oligonucleotides $c$ and $d$ are 5 '-CCGACACGAGCATGGACGAAG and 5'-CTGCTGAAACGGAACTCCCAC, respectively. The knockout genotype was verified by Southern blot analysis using DIG-label ed oligonucleotide c.

The heterozygous pial del etion strain, desi gnated $Y M C 1$, was allowed to sporulate on a minimal sporulation plate at $30^{\circ} \mathrm{C}$ for 1 week. The asci formed were dissected under a microscope using the micromanipulator; the spores were placed on a YPD plate and incubated at $30^{\circ} \mathrm{C}$. Colonies formed were replicaplated onto SC-Trp plates to test for Trp axotrophy.

\section{Assays}

The small-drop chemotaxis assay was performed essentially as described (Konijn and Van Haastert 1987; Insall et al. 1996). The microneedle chemotaxis experiment was performed as follows. Cells were devel oped in shaking suspension for 5-6 hr, washed and resuspended in PM buffer ( $5 \mathrm{mM} \mathrm{N} \mathrm{a}_{2} \mathrm{HPO}_{4}, 5 \mathrm{mM} \mathrm{KH}_{2} \mathrm{PO}_{4}$, and $2 \mathrm{~mm} \mathrm{M} \mathrm{MSO}_{4}$ ) at $10^{6}$ cells/ml. A $20-\mu \mathrm{l}$ drop of cell suspension was placed in a chamber made up of a glass cover slide and a rectangular metal frame of $8 \mathrm{~mm}$ in height. Cells were al lowed to settle at room temperature for 5-10 min and attach onto the glass surface. A gentle wash was done by adding and removing $1 \mathrm{ml}$ of DB. Two milliliters of DB was then added to the chamber and the chemotactic stimulation was provided by a microneedle, filled with $100 \mu \mathrm{M}$ CAMP solution, positioned with the aid of an inverted microscope and a micromani pulating sys- 
tem. M ovement of cells was monitored and recorded with a TV camera.

Cyclic GMP accumulation in response to CAM P stimulation was measured as described ( $M$ ato et al. 1977) using an isotope dilution assay kit (Amersham International plc, TRK 500). Each time point was assayed in duplicate and the assay was repeated at least twice for each cell line with similar results.

F-actin levels were measured by a modification of the method of Hall et al. (1988) as described (Insall et al. 1996).

To examine the effects of chemoattractant stimulation of adenylyl cyclase in vivo, cells starved for $5 \mathrm{hr}$ were stimulated with $10 \mu \mathrm{M} 2$ 2'-deoxy-CAMP and CAM P accumulation measured essentially as described (Segall et al. 1995) using an isotope diIution kit (Amersham International plc, TRK 432). In vitro adenylyl cyclase assays were performed essentially as described (Theibert and Devreotes 1986) on 5-hr developed cells except that the concentration of unlabeled ATP and CAMP in the reaction were increased to 0.3 and $0.5 \mathrm{~mm}$, respectively. $\mathrm{Mn}^{2+}$ stimulated activity was assayed with the presence of $5 \mathrm{~mm}$ $\mathrm{MnSO}_{4}$ in the reaction. GTP $\gamma \mathrm{S}$ stimulation was determined with the presence of $40 \mu \mathrm{m}$ of GTP $\gamma$ S and $1 \mu \mathrm{m}$ of CAMP in the lysate.

To reconstitute the GTPyS stimulation of ACA in lysates, supernatants from various cell lines were prepared in GLB at $8 \times 10^{7}$ cells $/ \mathrm{ml}$ as described above in the N orthern and Western blot analyses section. In typical reconstitution assays, either fresh supernatants (prepared at $8 \times 10^{7} \mathrm{cell} / \mathrm{s} / \mathrm{ml}$ ) or supernatants frozen at $-70^{\circ} \mathrm{C}$ and thawed immediately before reconstitution were mixed with equal volume of Iysates freshly prepared at $4 \times 10^{7}$ cells $/ \mathrm{ml}$ by filter lysis in the presence of $40 \mu \mathrm{M}$ of GTP $\gamma$ S. The reconstitution mixtures were incubated on ice for 8-12 min and 200- $\mu \mathrm{l}$ aliquots of the mixtures were assayed for adenylyl cyclase activity as described above. High speed supernatants gave the same results as the low speed supernatants; in most experiments low speed supernatants were used because they were more readily prepared. In the controls, GLB was used in place of supernatants from cells.

\section{Acknowledgments}

Wethank Dr. Rob Kay for the original Pianissimo REMI mutant HM 440. We thank Dr. Susan Michaelis and Dr. Konomi Fujimura-Kamada for help in disruption of the S. cerevisiae Pianissimo homolog. M.-Y. C. was supported by a Merck predoctoral fellowship. This work was supported by grants (GM 28007 and GM 34933) from the National Institutes of Health to P. N.D.

The publication costs of this article were defrayed in part by payment of page charges. This article must therefore be hereby marked "advertisement" in accordance with 18 USC section 1734 solely to indicate this fact.

\section{References}

Altschul, S.F., W. Gish, W. Miller, E.W. Myers, and D.J. Lipman. 1990. Basic local alignment search tool. J. Mol. Biol. 215: 403-410.

Broek, D., N. Samiy, O. Fasano, A. Fujiyama, F. Tamanoi, J. Northup, and M. Wigler. 1985. Differential activation of yeast adenylate cyclase by wild-type and mutant RAS proteins. Cell 41: 763-760.

Caterina, M.J. and P.N. Devreotes. 1991. Molecular insights into eukaryotic chemotaxis. FASEB J. 5: 3078-3085.

Chen, J., M. DeVivo, J. Dingus, A. Harry, J. Li, J. Sui, D.J. Carty, J.L. Blank, J.H. Exton, R.H. Stoffel, J. Inglese, R.J. Lefkowitz,
D.E. Logothetis, J.D. Hildebrandt, and R. Iyengar. 1995. A region of adenylyl cyclase 2 critical for regulation by $G$ protein $\beta \gamma$ subunits. Science 268: 1166-1169.

Chen, M.-Y., P.N. Devreotes, and R.E. Gundersen. 1994. Serine 113 is the site of receptor-mediated phosphorylation of the Dictyostelium $\mathrm{G}$ protein $\alpha$-subunit $\mathrm{G} \alpha 2$. J. Biol. Chem. 269: 20925-20930.

Chen, M.-Y., R.H. Insall, and P.N. Devreotes. 1996. Signaling through chemoattractant receptors in Dictyostelium. Trends Genet. 12: 52-57.

Crechet, J.-B., P. Poullet, M.-Y. Mistou, A. Parmeggiani, J. Camonis, E. Boy-M arcotte, F. Damak, and M. Jacquet. 1990. Enhancement of the GDP-GTP exchange of RAS proteins by the carboxyl-terminal domain of SCD25. Science 248: 866868.

Dahle, C. and D. Macfarlane. 1993. Isolation of RN A from cells in culture using catrimox-14 cationic surfactant. BioTechniques 15: 1102-1105.

Devreotes, P.N. 1994. G protein-linked signal ing pathways control the developmental program of Dictyostelium. Neuron 12: 235-241.

Devreotes, P.N. and S.H. Zigmond. 1988. Chemotaxis in eukaryotic cells: A focus on leukocytes and Dictyostelium. Annu. Rev. Cell Biol. 4: 649-686.

Devreotes, P., D. Fontana, P. Klein, J. Sherring, and A. Thei bert. 1987. Transmembrane signaling in Dictyostelium. Methods Cell Biol. 28: 299-331.

Dohlman, H.G., J. Thorner, M.G. Caron, and R.J. Lefkowitz. 1991. Model system for the study of seven-transmembranesegment receptors. Annu. Rev. Biochem. 60: 653-688.

Felder, C.C., R.Y. Kanterman, A.L. Ma, and J. Axelrod. 1989. A transfected $\mathrm{ml}$ muscarinic acetylcholine receptor stimulates adenylate cyclase via phosphatidylinositol hydrolysis. J. Biol. Chem. 264: 20356-20362.

Firtel, R.A. 1995. Integration of signaling information in controlling cell-fate decisions in Dictyostelium. Genes \& Dev. 9: 1427-1444.

Gilman, A.G. 1984. G proteins and dual control of adenylate cyclase. Cell 36: 577-579.

- - - 1987. G proteins: Transducers of receptor-generated signals. Annu. Rev. Biochem. 56: 615-649.

Hadwiger, J.A., S. Lee, and R.A. Firtel. 1994. The $\mathrm{G} \alpha$ subunit $\mathrm{G} \alpha 4$ couples to pterin receptors and identifies a signaling pathway that is essential for multicellular development in Dictyostelium. Proc. Natl. Acad. Sci. 91: 10566-10570.

Hall, A.L., A. Schlein, and J. Condeelis. 1988. Relationship of pseudopod extension to chemotactic hormone-induced actin polymerization in amoeboid cells. J. Cell Biochem. 37: 285299.

Hall, A.L., V. Warren, and J. Condeelis. 1989. Transduction of the chemotactic signal to the actin cytoskeleton of Dictyostelium discoideum. Dev. Biol. 136: 517-525.

Hoffman, C.S. and F. Winston. 1991. Glucose repression of transcription of the Schizosaccharomyces pombe fbpl gene occurs by a CAMP signaling pathway. Genes \& Dev. 5: 561571.

Hoffman, C.S. and F. Winston. 1990. Isolation and characterization of mutants constitutive for expression of the fbpl gene of Schizosaccharomyces pombe. Genetics 124: 807-816.

Howard, P.K., K.G. A hern, and R.A. Firtel. 1988. Establishment of a transient expression system for Dictyostelium discoideum. Nucleic Acids Res. 16: 2613-2623.

Insall, R., A. Kuspa, P.J. Lilly, G. Shaulsky, L.R. Levin, W.F. Loomis, and P. Devreotes. 1994. CRAC, a cytosolic protein containing a pleckstrin homology domain, is required for receptor and $\mathrm{G}$ protein-mediated activation of adenylyl cy- 
clase in Dictyostelium. J. Cell Biol. 126: 1537-1545.

Insall, R.H., J. Borleis, and P.N. Devreotes. 1996. The aimless RasGEF is required for processing of chemotactic signals through G-protein-coupled receptors in Dictyostelium. Curr. Biol. 6: 719-729.

Isshiki, T., N. M ochizuki, T. Maeda, and M. Yamamoto. 1992. Characterization of a fissi on yeast gene, gpa2, that encodes a $\mathrm{G} \alpha$ subunit involved in the monitoring of nutrition. Genes \& Dev. 6: 2455-2462.

Ito, H., Y. Funkuda, K. Murata, and A. Kimura. 1983. Transformation of intact cells treated with alkali cations. J. Bacteriol. 153: 163-168.

Johnson, R.L., R.A. Vaughan, M.J. Caterina, P.J. Van Haastert, and P.N. Devreotes. 1991. Overexpression of the CAMP re ceptor 1 in growing Dictyostelium cells. Biochemistry 30: 6982-6986.

Jones, S., M .-L. Vignais, and J.R. Broach. 1991. The CDC25 protein of Saccharomyces cerevisiae promotes exchange of guanine nucleotides bound to Ras. Mol. Cell. Biol. 11: 26412646.

Kataoka, T., D. Broek, and M. Wigler. 1985. DN A sequence and characterization of the $\mathrm{S}$. cerevisiae gene encoding adenylate cyclase. Cell 43: 493-505.

Kay, R.R. 1994. Differentiation and patterning in Dictyostelium. Curr. Opin. Genet. Dev. 4: 637-641.

Kesbeke, F., B.E. Snaar-Jagal ska, and P.J.M. Van Haastert. 1988. Signal transduction in Dictyostelium fgd $A$ mutants with a defective interaction between surface CAMP receptors and a GTP-binding regulatory protein. J. Cell Biol. 107: 521-528.

Klein, P.S., T.J. Sun, C.L. Saxe III, A.R. Kimmel, R.L. Johnson, and P.N. Devreotes. 1988. A chemoattractant receptor controls development in Dictyostelium discoideum. Science 241: 1467-1472.

Konijn, T.M. and P.J.M. Van Haastert. 1987. Measurement of chemotaxis in Dictyostelium. Meth. Cell Biol. 28: 283-298.

Kuspa, A. and W.F. Loomis. 1992. Tagging devel opmental genes in Dictyostelium by restriction enzyme-mediated integration of plasmid DN A. Proc. Natl. Acad. Sci. 89: 8803-8807.

Kuwayama, H., S. Ishida, and P.J.M. Van Haastert. 1993. N onchemotactic Dictyostelium discoideum mutants with altered CGMP signal transduction. J. Cell Biol. 123: 14531462.

Levitzki, A. 1988. Transmembrane signalling to adenylate cyclase in mammalian cells and in Saccharomyces cerevisiae. Trends Biochem. Sci. 13: 298-301.

Lilly, P.J. and P.N. Devreotes. 1995. Chemoattractant and GTP $y$ S-mediated stimulation of adenylyl cyclase in Dictyostelium requires translocation of CRAC to membranes. J. Cell Biol. 129: 1659-1665.

Lilly, P., L. Wu, D.L. Welker, and P.N. Devreotes. 1993. A Gprotein $\beta$-subunit is essential for Dictyostelium development. Genes \& Dev. 7: 986-995.

Lorenz, M.C., R.S. Muir, E. Lim, J. M cElver, S.C. Weber, and J. Heitman. 1995. Gene disruption with PCR products in Saccharomyces cerevisiae. Gene 158: 113-117.

Maeda, M., L. Aubry, R. Insall, C. Gaskins, P.N. Devreotes, and R.A. Firtel. 1996. Seven helix chemoattractant receptors transiently stimulate mitogen-activated protein kinase in Dictyostelium. J. Biol. Chem. 271: 3351-3354.

Mato, J.M., F.A. Krens, P.J. van Haastert, and T.M . Konijn. 1977. 3':5'-cyclic AM P-dependent 3':5'-cyclic GM P accumulation in Dictyostelium discoideum. Proc. Natl. Acad. Sci. 74: 2348-2351.

Milpetz, F., P. Argos, and B. Persson. 1995. TMAP: A new email and WWW service for membrane-protein structural predictions. Trends Biochem. Sci. 20: 204-205.
M usacchio, A., T. Gibson, P. Rice, J. Thompson, and M. Saraste 1993. The PH domain: A common piece in the structural patchwork of signalling proteins. Trends Biochem. Sci. 18: 343-348.

N adin-Davis, S.A., A. N asim, and D. Beach. 1986. Involvement of ras in sexual differentiation but not in growth control in fission yeast. EMBO J. 5: 2963-2971.

N ocero, M., T. Isshiki, M. Yamamoto, and C.S. Hoffman. 1994. Glucose repression of fbp1 transcription of Schizosaccharomyces pombe is partially regulated by adenylate cyclase activation by a $\mathrm{G}$ protein $\alpha$ subunit encoded by gpa2 (git8). Genetics 138: 39-45.

Parent, C.A. and P.N. Devreotes. 1995. Isolation of inactive and $G$ protein-resistant adenylyl cyclase mutants using random mutagenesis. J. Biol. Chem. 270: 22693-22696.

- - . 1996. M olecular genetics of signal transduction in Dictyostelium. Annu. Rev. Biochem. 65: 411-440.

Persson, B. and P. Argos. 1994. Prediction of transmembrane segments in proteins utilising multiple sequence alignments. J. Mol. Biol. 237: 182-192.

Pitt, G.S., N. Milona, J. Borleis, K.C. Lin, R.R. Reed, and P.N Devreotes. 1992. Structurally distinct and stage-specific adenylyl cyclase genes play different roles in Dictyostelium development. Cell 69: 305-315.

Sambrook, J., E.F. Fritsch, and T. Maniatis. 1989. Molecular cloning: A laboratory manual, 2nd ed. Cold Spring Harbor Laboratory Press, Cold Spring Harbor, NY.

Segall, J.E., A. Kuspa, G. Shaulsky, M. Ecke, M. M aeda, C. Gaskins, R.A. Firtel, and W.F. Loomis. 1995. A MAP kinase necessary for receptor-mediated activation of adenylyl cyclase in Dictyostelium. J. Cell Biol. 128: 405-413.

Spisani, S., M.C. Pareschi, M. Buzzi, M. Colamussi, C. Biondi, S. Traniello, G.P. Zecchini, M.P. Paradisi, I. Torrini, and M.E. Ferretti. 1996. Effect of cyclic AMP level reduction on human neutrophil responses to formylated peptides. Cell Signal. 8: 269-277.

Sun, T.J., P.J.M. Van Haastert, and P.N. Devreotes. 1990. Surface CAM $P$ receptors mediate multiple responses during development in Dictyostelium: Evidenced by antisense mutagenesis. J. Cell Biol. 110: 1549-1554.

Sunahara, R.K., C.W. Dessauer, and A.G. Gilman. 1996. Complexity and diversity of mammalian adenylyl cyclases. Annu. Rev. Pharmacol. Toxicol. 36: 461-480.

Sussman, R. and M. Sussman. 1967. Cultivation of Dictyostelium discoideum in axenic medium. Biochem. Biophys. Res. Commun. 29: 53-55.

Tanaka, K., M. N akafuku, T. Satoh, M.S. Marshall, J.B. Gibbs, K. Matsumoto, Y. Kaziro, and A. Toh-e. 1990. S. cerevisiae genes IRA 1 and IRA2 encode proteins that may be functionally equivalent to mammalian ras GTPase activating protein. Cell 60: 803-807.

Tang, W.-J. and A.G. Gilman. 1991. Type-specific regulation of adenylyl cyclase by $G$ protein $\beta \gamma$ subunits. Science 254: 1500-1503.

Theibert, A. and P.N . Devreotes. 1986. Surface receptor-mediated activation of adenylate cyclase in Dictyostelium. Regulation by guanine nucleotides in wild-type cells and aggregation deficient mutants. J. Biol. Chem. 261: 15121-15125.

Thevelein, J.M. 1992. The RAS-adenylate cyclase pathway and cell cycle control in Saccharomyces cerevisiae. Antonie Leeuwenhoek 62: 109-130.

Toda, T., I. Uno, T. Ishikawa, S. Powers, T. Kataoka, D. Broek, S. Cameron, J. Broach, K. M atsumoto, and M. Wigler. 1985. In yeast, RAS proteins are controlling el ements of adenylate cyclase. Cell 40: 27-36.

Verghese, M.W., K. Fox, L.C. M cPhail, and R. Snyderman. 1985. 
Chemoattractant-elicited alterations of CAMP levels in human polymorphonuclear leukocytes require a $\mathrm{Ca} 2+$ dependent mechanism which is independent of transmembrane activation of adenylate cyclase. J. Biol. Chem. 260: 67696775.

Wigler, M., J. Field, S. Powers, D. Broek, T. Toda, S. Cameron, J. Nikawa, T. Michaeli, J. Colicelli, and K. Ferguson. 1988. Studies of RAS function in the yeast Saccharomyces cerevisiae. Cold Spring Harbor Symp. Q uant. Biol. 53: 649-655.

Wu, L., R. Valkema, P.J. Van Haastert, and P.N. Devreotes. 1995. The $G$ protein $\beta$ subunit is essential for multiple re sponses to chemoattractants in Dictyostelium. J. Cell Biol. 129: 1667-1675.

Yamawaki-Kataoka, Y., T. Tamaoki, H.-R. Choe, H. Tanaka, and T. Kataoka. 1989. Adenylate cyclases in yeast: A comparison of the genes from Schizosaccharomyces pombe and Saccharomyces cerevisiae. Proc. Natl. Acad. Sci. 86: 56935697.

Young, D., M. Riggs, J. Field, A. Vojtek, D. Broek, and M. Wigler. 1989. The adenylyl cyclase gene from Schizosaccharomyces pombe. Proc. Natl. Acad. Sci. 86: 7989-7993.

Zhang, G., Y. Liu, A.E. Ruoho, and J.H. Hurley. 1997. Structure of the adenylyl cyclase catalytic core. Nature 386: 247-253. 


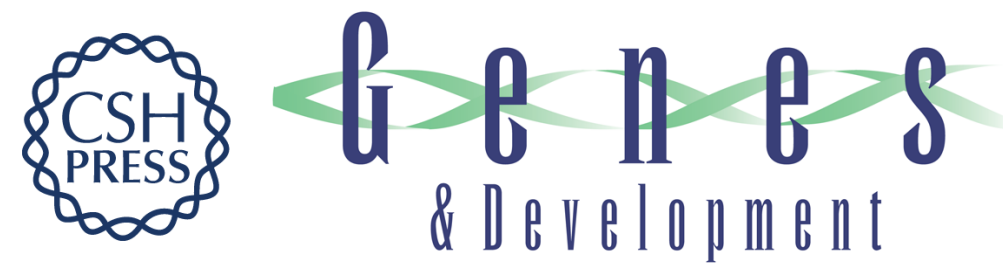

\section{A novel cytosolic regulator, Pianissimo, is required for chemoattractant receptor and G protein-mediated activation of the 12 transmembrane domain adenylyl cyclase in Dictyostelium}

Mei-Yu Chen, Yu Long and Peter N. Devreotes

Genes Dev. 1997, 11:

Access the most recent version at doi:10.1101/gad.11.23.3218

$\begin{array}{ll}\text { References } & \begin{array}{l}\text { This article cites } 64 \text { articles, } 30 \text { of which can be accessed free at: } \\ \text { http://genesdev.cshlp.org/content/11/23/3218.full.html\#ref-list-1 }\end{array}\end{array}$

License

Email Alerting Receive free email alerts when new articles cite this article - sign up in the box at the top Service right corner of the article or click here.

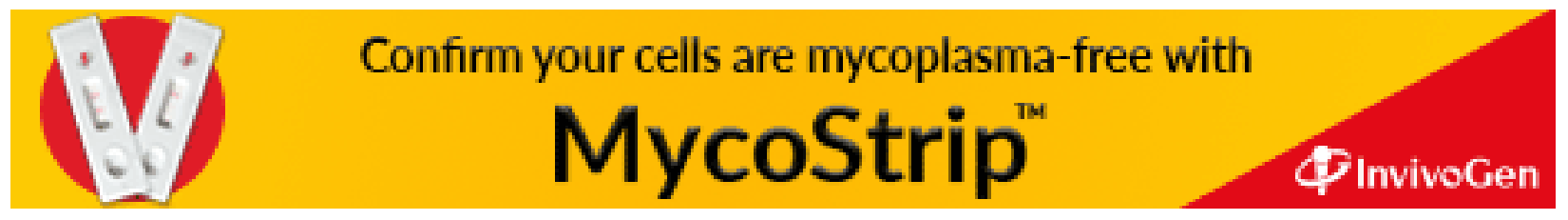

